\title{
Inbreeding and building up small populations of stingless bees (Hymenoptera, Apidae)
}

\author{
Paulo Nogueira-Neto ${ }^{1}$
}

\begin{abstract}
A study of the viability of small populations of Hymenoptera is a matter of importance to gain a better zoological, ethological, genetical and ecological knowledge of these insects, and for conservation purposes, mainly because of the consequences to the survival of colonies of many species of bees, wasps, and ants. Based on the WHITING (1943) principle, KERR \& VENCOVSKI (1982) presented a hypothesis that states that viable populations of stingless bees (Meliponini) should have at least 40 colonies to survive. This number was later extended to 44 colonies by KERR (1985). This would be necessary to avoid any substantial amount of homozygosis in the pair of chromosomic sexual loci, by keeping at least six different sexual gene alleles in a reproductive population. In most cases this would prevent the production of useless diploid males. However, several facts weigh against considering this as a general rule. From 1990 to 2001, 287 colony divisions were made, starting with 28 foundation colonies, in the inbreeding and population experiments with the Meliponini reported here. These experiments constitute the most extensive and longest scientific research ever made with Meliponini bees. In ten different experiments presented here, seven species (one with two subspecies) of Meliponini bees were inbred in five localities inside their wide-reaching native habitats, and in two localities far away from these habitats. This was done for several years. On the whole, the number of colonies increased and the loss of colonies over the years was small. In two of these experiments, although these populations were far $(1,000 \mathrm{~km}$ and $1,200 \mathrm{~km})$ from their native habitat, their foundation colonies were multiplied successfuly. It was possible to build up seven strong and three expanding medium populations, starting with one, two, three or even five colonies. However, in six other cases examined here, the WHITING (1943) principle and the hypothesis of KERR \& VENCOVSKI (1982) and KERR (1985), possibly hold up. In two other cases, the results are still unclear. Outside native habitats, most inbreeding experiments failed, possibly because of conditions that cause ecological stress. Although much more data are still needed, a new working hypothesis on the molecular level was presented to explain the results of the experiments described here. In the absence of any considerable stress, and in the eventuality of a good nutritive situation, even individual bees that are homozygous in the pair of chromosomic sexual locus would produce a sufficient amount of a sex determining substance. Therefore, the female genes of all the diploid individuals of a colony, both homozygous and heterozygous, would be activated. However, situations of considerable stress would cause a poor physiological and nutritive condition. This, together with homozygosis in the pair of chromosomic sexual locus, would lead to a smaller production of the sex determining substance. When this happens in the diploid homozygous individuals of a colony, in relation to sex, only male genes are activated. As a result, all such homozygous diploid bees of the colony become useless males. However, when there is a heterozygous situation in the chromosomic sexual locus of all bees of a colony, all diploid individuals would produce a high amount of the sex determining substance. Consequently, all diploid individuals of such a colony would become females (queens
\end{abstract}

1) Instituto de Biociências, Universidade de São Paulo. Caixa Postal 11461, 5422-970 São Paulo, São Paulo, Brasil. 
and workers). Stresses, including ecological stress, as well as the nutritive condition and the genetic situation in the chromosomic sexual loci, will have a key influence in the life and behavior of the Meliponini, including sex determination. In relation to genetic factors, hybrid vigour may often cause a greater production of biological substances. This may be due to the presence of a greater number of copies of allelic genes when there is heterozygosis. This is a hypothesis requiring further research. However, in the experiments presented here, this hypothesis seems to apply well to the production of a sex determining substance in bees (Apoidea) and other Hymenoptera.

KEY WORDS. Bee, genetics, imbreeding, population, meliponiculture, stresses, diploid males, sex determining bee substance

For the purpose of conservation and of gaining greater knowledge of stingless bee breeding ethology, it is very important to know if small populations of these insects are able to survive or not. In the vast highlands of Southeastern, Southern and Central Brazil (states of Goiás, Minas Gerais, São Paulo, Espírito Santo, Rio de Janeiro, Paraná, Santa Catarina, Rio Grande do Sul) most surviving forests are fragments or clusters of relatively small fragments. In the state of São Paulo, for instance, there are some 7,500 forest fragments or clusters of small fragments with more than 20 hectares in each cluster or fragment (data from satellite images and personal information from Marcia Hirota, SOS - Mata Atlântica-INPE Project).

In many insects, such as the Hymenoptera (bees, wasps, ants), normal males are haploid (they have only one set of chromosomes). Females are diploid (they have two sets of chromosomes). KERR \& VENCOVSKI (1982) and KERR (1985) presented a hypothesis, after considering the WHITING (1943) principle and the YOKOYAMA \& NEI (1979) paper on the loss of genetic variability with inbreeding. They also used the CORNUET (1980) formula for estimating the number of sexual alleles in bee reproductive populations. The LAIDLAW et al. (1956) formula may be used for the same purpose. First, CAMARGO $(1974,1979)$, and also KeRR (1974), stated that Melipona quadrifasciata Lepeletier, 1836, colonies fitted into the WHITING (1934) principle explanation of sex determination in several Hymenoptera. Later, KERR (1987) estimated the number of sexual alleles (of the sexual locus xo) that may exist in a population of $M$. compressipes fasciculata Smith, 1854. CARVALHO (2001) did the same in populations of M. scutellaris Latreille, 1811. KERR \& VENCOVSKI (1982) applied the WHITING (1934) principle to the practical breeding of the Meliponini in general. The KERR \& VENCOVSKI (1982) hypothesis stated that bee breeding populations would die out if they had less than 40 colonies. Later, Professor KERR (1985) increased this minimum number to 44 colonies, taking into account the calculations of YOKOAMA \& NEI (1979) as told by KERR et al. (1996). This population size would be necessary in order to keep six different allele genes related to the chromosomic sexual locus within the population. When the pair of chromosomes presenting this locus have homozygous (alike) allele genes in half of the diploid individuals of a colony, as WHITING (1943) found in the Braconid wasp now called Bracon hebetor Say, 1836, these individuals would always be diploid males. In the Meliponini, a colony in this situation would perish because males do not work to support it, even though their larvae eat as much food as the worker larvae do. 
However, the existence of scattered and isolated colonies of stingless bees and the results of most of the experiments presented here are in disagreement with the 40 or 44 minimum colony population hypothesis. My inbreeding experiments started in 1990, when I decided to gain a better understanding of the matter. As a result of this research, two new and major working hypotheses can be presented. Basically, for practical breeding (meliponiniculture) purposes, it is necessary to know if a very small inbred population could increase or not in spite of possible failures, whatever the failure may be.

The conclusions presented here should be considered by all breeders of stingless bees. According to the hypothesis of KERR \& VENCOVSKI (1982), and KERR (1985) only very common species of Meliponini could possibly be bred. It would be practically impossible to breed scarce or rare species successfully because, according to the hypothesis, a minimum of 40 (afterwards 44) colonies would be needed to start and maintain a population. In relation to most species of Meliponins, the average breeder cannot obtain this numbers of colonies to establish a meliponary. This paper discusses this crucial matter of meliponiculture.

Another key question will also be addressed here. On the molecular level, it is important to know how the genetic situation and how the number of ecological and other stress factors may influence the production of a sex determining substance, which probably would be a protein produced by the action of genes (DNA). A working hypothesis on the existence and action of this substance is discussed here. This will further the fruitiful debate started by CROzIER $(1971,1977)$ on the WHITING (1934) principle.

SNELL (1935) and afterwards CROZIER (1971, 1977: 264-265, 281), suggested that sex determination in the Hymenoptera could be attributed, not only to genes on a certain locus in a chromosome pair, as anticipated by the WHITING (1934) principle, but also to genes on several different loci. This hypothesis may now receive a new and broader interpretation.

The two major working hypothesis and related questions discussed here, were presented in a few short papers (NOGUEIRA-NETO 1990a, b, 1996a, b) and in my book (in Portuguese) on the life and breeding of stingless bees (NOGUEIRA-NETO 1997: 63-77). There is also a paper that I wrote on ecologic stress and other kinds of stress factors affecting Meliponini colonies (NOGUEIRA-NETO 1999). Now is the time to review the whole matter, in the light of the great extent of new data and new knowledge currently available. This is the chief purpose of this paper.

In the course of the experiments reported here, 287 colony divisions were made up to September 2001, starting with a total of 28 foundation colonies. This is by far the largest group of scientific experiments of any nature ever made with stingless bees. The data presented here give a general knowledge of what may happen when the Meliponini are inbred and what could be expected when establishing small populations of these important tropical and subtropical bees.

In this paper stingless bees are considered as a tribe (Meliponini) with two subtribes (Meliponina and Trigonina). Perhaps this may be generally accepted. See also MOURE (1951) on the Meliponinae as a subfamily. MICHENER (2000) proposed the tribe and other researchers suggested the subtribes here mentioned. A neighbour group should remain as Euglossini. 


\section{MATERIAL AND METHODS}

I started several experiments in 1990 , beginning with one or a few colonies (five or six) of Scaptotrigona postica (Latreille, 1807) as a foundation stock. I divided the colonies again and again (inbreeding), until I had several small stingless bee populations, 10 of which had more than 18 colonies, not counting the colonies that perished. I did this in different local areas that, as far as I knew, had no other colonies of the species being tested. However, if there were a few undetected colonies in these areas, this would not be genetically significant, according to the conclusions of the KERR \& VENCOVSKI (1982) and the KERR (1985) hypothesis. These authors stated, as mentioned earlier, that 40 or 44 colonies is the minimum number required for the survival of a population of stingless bees. It is also important to consider that my experiments were not made near large and continuous forests, where it would be difficult to find nests. Bee surveys cannot be conducted within cities. Experiments within urban areas were attempted in Itanhaém (Cibratel), São Paulo State but were not completed in São Paulo city. In the case of Melipona scutellaris, the nearest native colonies to my meliponaries are in Bahia State, approximately $1,000 \mathrm{~km}$ from the Luziania (Goiás) meliponary and some 1,200 km from the São Simão (São Paulo) meliponary.

Surveys conducted in the areas around my meliponaries nearly always failed to come across any other colonies of the species taking part in the inbreeding experiments. Details of the surveys are presented. The knowledge of local people was also borne in mind. In one case (Melipona quadrifasciata quadrifasciata Lepeletier 1863, in São Paulo city), I found evidence of genetic hybridization with outside bees of another subspecies (M. quadrifasciata anthidioides Lepeletier 1863). This experiment was ended.

The colonies of Melipona quadrifasciata, M. scutellaris, M. quinquefasciata Lepeletier, 1836, and $M$. rufiventris rufiventris Lepeletier, 1836, were moderately fed with a water (40\%) and sugar $(60 \%)$ syrup. Feeding was usually done once a month, but more frequently right after a colony division. In the experiments presented here, no colonies were fed with honey. The colonies of Tetragona clavipes (Fabricius, 1804), Scaptotrigona postica Latreille, 1807, and S. xanthotricha Moure, 1950, were fed with the syrup mentioned above, but much less frequently. No colonies received a pollen substitute. Inspections of the colonies were often made when a colony was fed, in order to minimize handling conditions that probably produce what I would call laboratory stress. Matings were not controlled in the experiments, to avoid causing stress and failure. Nonetheless, there is a record of all colony divisions and of life conditions in each colony. In each experiment the colonies have an individual number.

Colonies were sometimes reinforced with brood combs from colonies of the same genetic pool. In other words, they were reinforced only with brood combs of colonies taking part in the same particular inbreeding and population experiment. The concept of participating in a same population genetic pool is of key importance for accurate interpretation of experiment results. Generally, brood comb reinforcements were made during the first months after a colony division. Because of 
miscalculations, one of the divided colonies may not have received a sufficient brood. In these cases, brood combs from a "sister" colony were given to the colony in need. This was also done in other situations when needed. In the inbreeding and population building experiments mentioned here, this was done a limited number of times. The reinforced colony usually recovered, but not always. The number of population foundation colonies in all the experiments is mentioned here. Colonies were also reinforced by changing places with stronger colonies of the same experiment. This last method was quite effective with M. quadrifasciata, M. scutellaris, $M$. rufiventris, $S$. xanthotricha, Tetragona clavipes and could probably also be used with many other Meliponini. Note, however, that it was adopted with reservation at first because of its potential to induce fighting among the bees. The change basically reinforces the receiving colonies with more non-laying workers, not with males or queens. Laying workers presumably live inside the nest in the laying phase of their life. Small-scale fighting was occasionally observed when this reinforcement method was used, but it was not a serious problem.

A laying queen probably has a life span of about three years (average). When a queen dies, she is replaced by a new one. This situation is similar to what occurs when a colony is divided and a recently fecundated queen starts laying in one of the two divided colonies. In the mid-and-long-term life of a colony subjected to repeated inbreeding, the counting of probable queen replacements is very important to reach valid conclusions. When a colony is to be divided, layng queens should have been marked to determine if they remained in the old colony or if they went with the new colony, but this was seldom done. However, an average three year life age expectancy is a valid consideration for Meliponini laying queens. Genetically, each natural queen replacement is equivalent to a man-made colony division. I also took this into account in my data. The queens were allowed to mate freely, with no controls, in order to avoid stress.

Because of logistic difficulties, divisions were discontinued in some experiments after the total population had more than 25 or 30 colonies. Colony divisions in the present experiments were made personnally by me, together with helpers, except for one division in a M. quadrifasciata anthidioides experiment in Campinas (São Paulo). I also performed most of the initial divisions follow-ups and periodical general colony inspections. A written report of these activities was kept.

When presenting the number of colonies produced by divisions, the first queen of a population foundation colony of an experiment was not counted. This queen was not produced by known or controled divisions, except in the second fase of the Limeira (São Paulo) inbreeding and population building experiment. However, after surviving about three years, a foundation colony presumably has a new queen, because a queen is usually replaced by that time. When this would happen, this new queen was counted, because its status was similar to that of all the other new queens in the experiment. This has been computed in the data presented in the Results and Discussion sections.

Where reported, colonies less than six months old were placed in a special category, clearly stated in this paper. When alive, these colonies were not counted in the results used for reaching conclusions. They were counted as valid colonies only after they were over six months old and if they reared brood. However, these 
young colonies were counted when they died, except if they did not rear brood before dying. This is important, because in my view only the Meliponini colonies that survive well, that rear brood and that are six months old or more can be considered normal colonies. They probably have no problems with diploid males and with undue stress. The cause of death, whether it be serious stress or possibly a disease or some other reason, could be very difficult to distinguish. Therefore, to avoid needless confusion or mistakes, all colony deaths were computed separately according to age bracket as an initial approach. Nearly all deaths were also considered as a whole, in each experiment. However, the clear cases of death due to accidents, the cases in which the colonies did not even start to rear brood, and the cases when the colonies were removed from one experiment and sent to another region, were all recorded separately and stated clearly. Another consideration is that the laying of sterile eggs by queens is a malfunction and has nothing to do with the production of diploid males. This malfunction has been mentioned here when clearly the case.

Colonies that are persistently and unusually weak, were stated as such. This is important, because their condition may indicate some disease or genetic problem, such as the presence of diploid males. However, most weak colonies were feeble for only a short period and then recovered. Rarely was a colony weak for a long time. Weak colonies nearly always died off or recovered well.

\section{RESULTS}

Between 1990 and September 2001, several inbreeding and population building experiments were conduted with Meliponin bees, as will be described.

In Itanhaém, on São Paulo States's Atlantic coast, the meliponary was inside a residencial development (Cibratel 1) near the ocean. There is a small (circa 10 ha) swampy forest some $500 \mathrm{~m}$ away and a larger one some $2,500 \mathrm{~m}$ from the meliponary. Near this larger forest, 2 or 3 Melipona quadrifasciata quadrifasciata bees were captured in 1966, visiting Vernonia westiniana Less flowers. A single $M$. quadrifasciata anthidioides bee was captured also in V. westiniana flowers, in 1993, some 1,000 m away from my hives. These native bees were the only ones of this species found in the area around my meliponary. The inbreeding and population experiment began in 1991 with a single colony of Melipona quadrifasciata quadrifasciata, from the Itajaí Valley, near Blumenau (Santa Catarina). These bees are a little larger than the local native quadrifasciata, and the adults that begin to fly are somewhat more chesnut than black, their basic colour. All M. quadrifasciata have yellow stripes on the back of four abdominal terga, interrupted in the middle in $M$. quadrifasciata anthidioides.

I will now present a summary of the data on the inbreeding and population building experiments with the Melipona quadrifasciata quadrifasciata colony age structure in Itanhaém (São Paulo) in December 1998. The remaining colonies were later moved to Limeira (São Paulo). Foundation stock colony: number 1. Colonies that died before they started building brood combs: none. Colonies alive under six months that already started building brood cells: none. Colonies that died under six months but already having built brood combs: none. Colonies alive between six months and three years old, numbers 14, 16, 18, 19, 20, 21, 22, 23, 24, 25, 26, 27. 
Colonies that died between six months and three years old: numbers 1, 12, 13, 17 . Colonies alive between three years and six years old: numbers $3,4,5,6,7,9,10$, 11. Colonies that died between three and six years old: number 8 . Colony alive at six years or older: number 2. Colonies that died over six years old: none.

The site of this experiment was changed because the property was sold. The M. quadrifasciata quadrifasciata colonies were moved (on November 30,1998) to Tabajara Farm, in Limeira, on the highlands of São Paulo State, some $190 \mathrm{~km}$ to the NE of Itanhaém.

Reviewing the whole experiment briefly, five colonies died in Itanhaém as already mentioned. One colony (number 3 ) remained alive in Itanhaém. Another colony (number 27), after remaining some time in Limeira, was sent to Cambory on the NE coast of São Paulo State. 20 other colonies from Itanhaém became the whole foundation stock in new site in Limeira. Eighteen colonies were divided in Limeira. Since the beginning of the experiment the divisions made in both stages of the whole experiment produced 45 colonies from a single foundation colony in Itanhaém. Each received a number. In the Limeira stage, the complete stock had 39 colonies, sent away or dead or alive by September 2001. Three of these colonies $(31,32,37)$ did not build brood combs and, therefore, were not counted in the discussion section of this paper. However, another 19 colonies that died later built combs (numbers 7, 19, 21, 25, 26 died in the year 1999; numbers $3,5,9,14,15,22,23,28,30,35,36,38,41$ died in the year 2000; number 42 died in 2001). In September 2001, 16 colonies were alive (numbers 2, 4, 6, 10, 11, 16, 18, 20, 29, 33, 34, 39, 40, 43, 44, 45). Three of these live colonies were weak: numbers $20,33,45$. Generally speaking, soon after the end of 1998, when this population was moved to Limeira, there was a clear decline in the condition of its colonies, in spite of plentiful feeding. The colonies numbered 28 and up were produced by divisions made in Limeira. The colonies numbered 27 and down were produced by divisions made in Itanhaém except for the foundation colony that came from the Itajaí Valley (Santa Catarina).

In Itanhaém, Cibratel, São Paulo State, an experiment was started with a Melipona scutellaris colony from Lençois (received from Piatã), Bahia State, in 1993. This colony and a daughter colony perished. Another experiment began later with a colony of the same species, but from Pernambuco State (1996). It also had a daughter colony that died. The older colony was first sent to Limeira. Later, in January 1999, it was sent on to São Simão (São Paulo) with another daughter colony. Both colonies died after remaining there 10 months, always displaying symptons of weakness and possibly having queens with sterile-egg-laying problems.

In São Paulo city, my experimental meliponary is inside Jardim Guedala, a residential area with many houses, gardens and trees. The inbreeding and population experiment began in 1991 with a single foundation colony of M. quadrifasciata quadrifasciata from the Itajaí Valley, near Blumenau (Santa Catarina). It had (December 1998) 11 live colonies and was more than one year old. Contamination with $M$. quadrifasciata anthidioides genes occurred from an unknown source. This led to the termination of the experiment. However, most of these colonies were there in September 2001 and their bees are still M. quadrifasciata quadrifasciata or hybrids. Colony divisions: 10 (the foundation colony was not counted). 
At the Fazenda São Quirino, in Campinas (São Paulo), 90 km NW from São Paulo city, the meliponary is in an orchard, in a valley near many Eucalyptus spp. trees and also near a forest of native trees which I planted. Some $300 \mathrm{~m} \mathrm{NW}$ of this spot there is a young native woodland. Some $2 \mathrm{~km}$ away is the big city of Campinas. The inbreeding and population building experiment started in 1990 with a Melipona quadrifasciata anthidioides colony. It was a single survival from a stock made up of colonies that came mostly from Cosmópolis but also from Amparo, Pariquera Açu, and possibly a native colony from Campinas, all in São Paulo State. Colonies of Melipona quadrifasciata quadrifasciata from the Santa Catarina State were also kept in this meliponary before 1974 but did not survive. They died off or were robbed by people long before 1990. The foundation colony of the experiment was stolen in 1991, together with its two daughter colonies. These three colonies were not counted in our results. The experiment was started up again in 1991, with a colony of bees of the same stock, found in a nearby apiary-meliponary. Later, only one wild colony of this species was found, in a radius of $1,400 \mathrm{~m}$, possibly a swarm from the meliponary.

Below, I will present a summary of the data of this inbreeding and population building experiment with Melipona quadrifasciata anthidioides at the Fazenda São Quirino, Campinas. Population age structure as existing in September 2001. Stock foundation colony: number 1 . Colonies that died before starting to build brood combs: none. Colonies alive under six months that already started building brood combs: none. Colonies that died under six months of age: none. Colony alive between six months and three years old: number 28 . Colony number 11 was moved to another locality. Colonies that died between six months and three years old: numbers 22,27 . Colonies alive between three years and six years of age: numbers $15,16,17,18,19,20,21,23,24,25,26$. Colonies alive over six years old: numbers $1,2,3,4,5,6,7,8,9,10,12,13,14$. Colonies that died over six years old: none.

The inbreeding and population building experiment with Tetragona clavipes bees began in 1992, in the same Fazenda São Quirino, Campinas, with a single colony that had been in the meliponary since 1959. In 2001, it was 42 years old. It came from Cosmópolis (São Paulo), some $43 \mathrm{~km}$ North of Campinas. A swarm of this colony probably colonized a natural hollow in a Spathoidea sp. tree, about 150 $\mathrm{m}$ from the meliponary. This occurred in 1986. I do not know of any other colonies of this species in Campinas. A local bee hunter (Tonal Francisco) has also never seen any colonies of this bee there, except for those mentioned here. A survey was made in a $1,400 \mathrm{~m}$ radius around the meliponary, and did not uncover any nests of these species within this radius or anywhere else.

In December 1999 and January 2000, the colonies resulting from three divisions had recovered well. However, after two other colony divisions were made, also at this time, two colonies remained queenless. Each then received a royal cell (cocoon). One of these colonies recovered well but the other died out. I am mentioning this to show some of the difficulties encountered in colony divisions of Tetragona clavipes.

Below, a summary of the data of this inbreeding and population building experiment with $T$. clavipes at the Fazenda São Quirino, Campinas is presented. Population age structure as existing in September 2001. Foundation stock colony: 
number 1. Colonies alive under six months old, but that already started building brood cells: none. Colonies that died under six months of age: number 13 (with some brood cells). Colonies that died building brood combs: numbers 5, 27. Colonies that were moved away: none. Colonies alive, between six months and three years old: numbers 14-B, 15, 16, 17, 18, 19, 20, 21, 22, 24, 25, 26, 28, 30. Colonies that died between six months and three years old: numbers 2-A, 2-B, 6, 8, 14-A, 23. Colonies alive between three years and six years old: numbers 7, 9, 11, 12. Colony that died between three years and six years old: number 10. Colonies alive over six years old: number 1-A, 1-B, 3, 4. Colonies that died over six years old: none. Colony alive at 15 years of age: number 1-B. Colony alive at 42 years of age: number 1-A.

An inbreeding and population building experiment with Scaptotrigona postica began in 1991 with a group of six colonies in the same Fazenda São Quirino. The stock came mostly from Cosmópolis, dating back to 1946, but also received a laying queen sent by Luiz Juliani from Londrina (Paraná State), successfuly introduced in a colony of this species in 1960 (NOGUEIRA-NETO 1997: 220), and therefore, a stock that has been living at the Fazenda São Quirino for a long time. In January 1999, I saw two well-established colonies of this species in a hollow of a shady tree in Cambuí, a downtown residencial area in Campinas. These colonies are some $6 \mathrm{~km}$ west of the meliponary. No nests of this species were found in a 1,400 $\mathrm{m}$ radius survey around the meliponary.

The following is the summary of this inbreeding and population building experiment with Scaptotrigona postica at the Fazenda São Quirino. Population age structure as existing in September 2001. Foundation stock colonies: numbers $01,02,03,04,05$ including a queen from Londrina. Colonies alive under six months old that already started building brood cells: none. Colonies under six months old, that died: none. Colonies alive between the age of six months and three years: numbers 30,31 . Colonies between six months and three years old that died: none. Colonies alive between the age of three years and six years: numbers 21, 22, 24, 25 , 26, 27, 28. Colony between six months and three years old that died: number 5 . Colonies alive over six years old: numbers $10,12,13,14,16,17,18,19,20$. Colonies alive over nine years old: numbers 1,2, 3. Colonies numbers 4, 7, 8, 9, 17, 29 were sent to other places (São Paulo city, Itanhaém, Campinas (Fazenda Jatibaia).

At the Fazenda São Quirino, Campinas an inbreeding and population building experiment with Scaptotrigona xanthotricha bees began in 1995 with a single colony that came from Serra da Bocaina, São Paulo State, some $200 \mathrm{~km}$ $\mathrm{NE}$ of Campinas, brought by Luis Costa. 14 colonies of descendents were alive in September 1999. They were 13 months old in December 2000. The bees in half of these colonies were dark-colored and those in the other half were light-colored. Seven more colony divisions were made at the end of December 1999 and in January 2000. Three of these colonies were of light-colored bees and four were of dark-colored bees, as were their mother colonies. Therefore, there were 10 colonies of light-colored bees and 14 colonies of dark-colored Scaptotrigona Moure, 1942, bees in January 2000. However, in December 2000, there were only six colonies of light-colored bees. Four were sent to the Cosmópolis, Usina Ester meliponary, to preserve them from becoming dark-colored. Only two remained 
at the Campinas meliponary. Initially I thought that the colonies of dark-colored bees could be the result of a crossbreeding with $S$. postica males. I examined some of the dark bees with a stereoscopic, binocular microscope. At first, I had the impression that they were not quite as dark as $S$. postica. However, I did not find consistent differences. See the section of this paper on the discussion. I only noticed the dark-colored bees in September 1999. Before, no dark-colored bees had been seen in hives with $S$. xanthotricha colonies, although I did notice a dark tube entrance in February 1999, in one of the colonies where the bee population became dark. In the colonies where the bees have a dark body coloring the cerumen of their nest entrances is also dark. During this experiment (November 1995 to December 2000), only one dark colony died, during a frost on July 18, 2000. It was already weak. Two other colonies had also been weak for a long time, but survived. The experiment was discontinued because of the substitution of the light-colored bee colonies by dark-coloured colonies. However, it did show that, in 10 colonies that turned dark, this occurred when the light colored colonies had an average age of 21.3 months. A second fase of the experiment is scheduled to be conducted in Usina Ester, Cosmopolis (São Paulo), with only typical $S$. xanthotricha, in a meliponary with no $S$. postica colonies.

Another inbreeding and population experiment was started in 1993, also at the Fazenda São Quirino, Campinas, with a colony of Melipona rufiventris rufiventris from Luziânia (Goiás). It had a "daughter" colony. Both died in 1994, after two successive frosts during the winter.

Usina Ester, Cosmópolis, is about $43 \mathrm{~km}$ north of Campinas. The meliponary is near a sugar mill and also near riverside forests, surrounded by sugar cane plantations. Cosmópolis city is some $1.5 \mathrm{~km}$ from the meliponary. Approximately $4.5 \mathrm{~km}$ away from the meliponary, inside the city, there lives a stingless bee breeder that has a colony of Melipona quadrifasciata anthidioides. No other colonies of this bee are known to exist near the meliponary. In 1991, one foundation colony of $M$. quadrifasciata anthidioides from the same region was used to start an inbreeding and population building experiment there. Several colony divisions were made. Up to 1997,10 colonies were established (not counting the foundation colony) but seven of these colonies died, including the four-year-old foundation colony that probably had a new queen by then. In 1995, six colonies died. It was a crash year. The six colonies that died in 1995 were an average of 22.4 months old (13 months to 34 months). Therefore, they were not young colonies. In June 1998, there were nine dead colonies (numbers 1, 2, 3, 4, 5, 6, 7, 8,11) and only three colonies (numbers $9,10,12$ ) alive as of the beginning of the experiment (no deaths in the first four years). From June 1998 to June 2001, two other colonies died (numbers 9, 13). In July, August and September 2001, there was another population crash, causing the death of four colonies (numbers 10,15, 18, 19). During this crash, the presence of males was not noticed in these colonies. These four deaths brought the total number of colonies that died to 15 . One dead colony (number 21) was not counted in the discussion section of this paper because it died when it was little over one month old and had not started to build brood combs. In September 2001, there were five live colonies and in a normal state: one over three years old (number 12) and four

Revta bras. Zool. 19 (4): 1181 - 1214, 2002 
colonies between six months and three years old (numbers 14, 16, 17, 20). Several years ago, in one of the Cosmópolis colonies (number 10) there was a fight between workers. Several died and the queen was also found dead. In the Cosmópolis meliponary, many colonies of $M$. quadrifasciata anthidioides became increasingly weak before dying despite many cerumen pots with sugar syrup or honey inside their hives. These could indicate the presence of diploid males.

In 1994 a colony of Melipona rufiventris rufiventris was received by the Usina Ester meliponary, from the Fazenda Jatiara meliponary (Luziânia, Goiás). However, this colony was last seen alive in March 1995.

The Fazenda Aretuzina, São Simão (São Paulo), is about $50 \mathrm{~km}$ SE of Ribeirão Preto (São Paulo). The meliponary is in an orchard, in a small valley set among sugar cane plantations, near 80 hectares of second-growth cerrado (savanna), and a few hectares of a native tropical semi-deciduous riverine forest. Two kilometers away is the small city or village of Bento Quirino, in the municipality of São Simão. An inbreeding and population building experiment with Melipona rufiventris rufiventris bees began there in 1993, with a single colony that came from Luziânia, $100 \mathrm{~km} \mathrm{~S}$ of Brasília (Federal District) and some $900 \mathrm{~km}$ NW of São Simão. The nearest known living colonies belonging to the same species, according to Prof. Dr. João M.F. Camargo (communicated personally), were found on the Santa Carlota Farm, Cajuru (São Paulo), 32 km NE of São Simão and also in the Ecological Station of Jataí, some 25 km SW of São Simão, where my meliponary is located.

The following is the summary data on the inbreeding and population experiment with Melipona rufiventris rufiventris. Population age structure existing on the Fazenda Aretuzina, São Simão, in September 2001. Foundation stock colony: number 01 . Colony that died within two months and before starting to build brood combs: number 22 (not counted in the discussion section). Colonies alive under six months old, that already started building brood cells: none. Colonies that died between six months and three years old: numbers 1, 7, 18, 19, 23, 24, 25, 35 . Colonies alive between six months and three years old: numbers 14, 15, 16, 18, 20, $21,26,27,28,29,33,34,36$. Colonies alive between three years and six years old: numbers $5,6,8,9,10,11,12,13$. Colony that died between three and six years old: number 17. Colonies over six years old: numbers 2,3 . Colony that died over six years old: number 4 .

The inbreeding and building up population experiment with Melipona scutellaris bees from Pernambuco State, began in 1996, also on the Fazenda Aretuzina, São Simão, with two colonies sent by Renato Barbosa. There was also a third colony from the same population, but it was very weak and probably would not survive. It was merged with one of the other two foundation colonies early in the experiment. Among the colonies alive in September 2001, eight were obtained by colony divisions, between November 1999 and January 2000. Colony number 8 , one of the old colonies, was weak or relatively weak from February 2000 until March 2001, despite a reinforcement with brood combs and twice with adult bees. However, it became a strong colony later. Apparently, in this case as well as in other cases, something went wrong with the queen's ability to lay fertile eggs. This failure 
sometimes is total or at other times only partial. It obviously is a result of a general condition that has nothing to do with the production of diploid males. The problem can be solved by eliminating the defective queen, as I did in three cases. Another one of the existing colonies was two years old and died in January 2000, because its hive was occupied by $M$. mandacaia Smith, 1863, swarming bess. The colonies of this M. scutellaris experiment are far away $(1,200 \mathrm{~km})$ from the native habitat of the species. In the first days of 1999, a colony of M. scutellaris (number 12) and its daughter colony (number 13) were added to the 11 colonies present on the Fazenda Aretuzina. Both came from the Limeira meliponary, but the oldest of these colonies had first been in Itanhaém, before it was taken to São Paulo State. When both colonies arrived in São Simão they were already weak, one of which was extremely so. They received brood comb reinforcements from the São Simão meliponary colonies. However, despite the help, they were dead by October 1999. These two colonies probably did not add new genes to the genetic pool of the experiment, because they were too weak and remained less than 10 months in the São Simão meliponary. Their queens may have had egg fertility problems, a matter of some concern in relation to Meliponini breeding. Nonethess, for experiment discussion purposes, they were simply counted as dead members of the foundation stock of this population, present in the São Simão meliponary. Both colonies belonged to the same stock that came from Pernambuco State in 1996, as did the other M. scutellaris colonies from this meliponary. As already mentioned briefly, in October 2000 , a queen from a strong colony (number 7) of M. scutellaris was laying only non-fertile eggs. When the queen was removed, the colony was considered as technically dead, because it would last only about two more months with no queen and no brood. The colony, still populated by many adult bees, received two large brood combs with about 900 prepupae or pupae inside their cocoons. As a new colony it was given a new number (number 27). A couple of days later, a new queen began to lay normal eggs. This colony was then considered a new one. It developed well (September 2001).

The following is the summary data of this inbreeding and population building experiment with Melipona scutellaris, at the Fazenda Aretuzina, São Simão. Population age structure existing in September 2001. Foundation stock colonies numbers 1, 2, 3 (number 3 was soon united with number 2 ) and possibly also numbers 12 and 13 , that were alive in the experiment for only 10 months. Colonies that died before starting to build brood combs: none. Colonies that died under six mouths old: none. Colonies alive between six months and three years old: numbers $8,9,10,11,14,15,16,17,18,20,21,22,23,24,25,26,27.28$, $29,30,31,32$. Of these, colony 15 was soinewhat weak and had many young male bees. Colonies that died between six months and three years old: numbers $5,7,13$. Colony that died between three and six years old: number 12 . Colonies alive between three years and six years old: numbers 1, 2, 3, 4, 6. Colonies alive and over than six years old: none. Colonies that died over six years old: none. On the whole, the colonies that remained alive in this experiment were in good condition, comparing well with those that live in the region of Recife (Pernambuco), the source of the foundation stock of this research. 
The Fazenda Jatiara, in Luziânia, Central Brazil, is pratically an "island" of some 1,200 ha of mostly primitive cerrado-savannah, in Central Brazil. It is about $100 \mathrm{~km}$ south of Brasília. Two different stocks of Melipona scutellaris colonies from Northeastern Brazil were kept there. The first introduction (1993) came from Lençois, after being some time in Piatã, also in Bahia State. Both foundation colonies of the Lençóis stock, as well as a daughter colony, died in 1995. No colonies of this stock survived in my experiments. These $M$. scutellaris bees came from the same source of most bees in the CARVALHO (2001) experiment conducted at the Universidade Federal de Uberlândia (Minas Gerais).

A second introduction of M. scutellaris in Luziânia was made in 1996, with three colonies from the region of Recife. They were sent by Renato Barbosa. The following is the summary data of this inbreeding and building population experiment with Melipona scutellaris at the Fazenda Jatiara, Luziânia. Population age structure existing in September 2001. Foundation stock colonies: numbers 4, 5, 6 . Colonies numbers 1, 2, 3 belonged to the other stock that died out before this experiment began. Colonies less than six months old, that died before building brood combs: numbers $12,13,14,19$. They were not counted in the discussion section of this paper. Colonies that died between the age of six months and three years: numbers $4,6,7$. Colonies alive, with an age between six months and three years old: numbers $10,11,15,16,17,18,20,21,22$ (colony 17 is weak). Colonies that died at an age between three and six years old: none. Colonies alive with an age between three and six years old: numbers $5,8,9$.

The amount of colonies (numbers 12, 13, 14, 19) that died before building brood combs was greater than in other experiments presented here, chiefly because Jatiara Farm, in Luziânia, is far away (approximately 1,000 km) from São Paulo city were I am most of the time. Therefore, these four colonies did not receive the same attention that they would have had in more nearby experiments. Care is important, chiefly in the first weeks of life of colonies that are divided. They may not survive if they are not properly fed young in life. They must also have a minimum number of young bees and foragers, as well as a certain amount of protection against Forid flies and other enemies.

A colony of Melipona quinquefasciata, a species with subterranean nests, was brought to the Fazenda Jatiara, Luziânia, from a cerrado-savanna some $10 \mathrm{~km}$ away and placed in a special shelter where colonies live in hives covered by dry sand, except for the hive entrance. This shelter is built for colonies of the meliponini species that have subterranean nests and also protects colonies of other species from cold weather, including possible frosts. It was first designed and described by NOGUEIRA-NETO (1997: 130-131). Each shelter now measures a few meters long and $1 \mathrm{~m}$ wide inside, and is used to keep colonies protected in hives that are placed at least $20 \mathrm{~cm}$ below dry sand. The other colonies of this species, known in the region, are very few and live some $10 \mathrm{~km}$ from the meliponary. The colony, that was captured and placed in a shelter, was the foundation colony of the inbred population described here.

The following is the summary data of this inbreeding and building population experiment with Melipona quinquefasciata on the Fazenda Jatiara (Goiás). Population age structure existing in September 2001. Foundation colony: number 1. 
Colony that died under six months old, before building brood combs: number 14 . Therefore, this colony was not counted in the discussion section. Colony that died under six months old and after it already started building brood combs: number 17 . Colonies that died between six months and three years old: numbers 3,7 . Colonies alive between six months and three years old: numbers 4, 5, 8, 9, 10, 11, 12, 13, 15, 16, 18 (also number 6 , see below). Colonies that died between three and six years old: none. Colonies alive between three and six years old: numbers 1,2 . Colony that was sent to the São Simão meliponary: number 6 . The age bracket of the colony, counted before leaving the Jatiara meliponary, was between six months and three years. It is still alive and well in the São Simão meliponary (September 2001).

A colony of $M$. quadrifasciata quadrifasciata from the Itajaí Valley (Santa Catarina) was sent to the Fazenda Jatiara (Luziânia) in 1991, with a daughter colony. Both died. The same thing occurred there with a colony of $M$. subnitida Ducke, 1910, from the state of Rio Grande do Norte and later with its only daughter colony, that died in 1998. A colony of M. quadrifasciata anthidioides was received from São Simão in 1997. After five divisions, five colonies died (including the foundation colony) and only 1 remained alive, in September 2001. Among the colonies that died, one was nearly three months old and another one, almost 10 months old, when they perished.

\section{DISCUSSION}

The same results and conclusions of WHITING (1943) on the production of diploid males in inbred populations of the Braconid wasp Bracon hebetor, were also confirmed by several authors, in relation to Apis mellifera (Linnaeus, 1758) among whom are MACKENSEN (1951), ROTHENBULER (1957), CUNHA \& KERR (1957), and WOYKE (1963), and in relation to the Meliponini, by CAMARGO $(1974,1979)$, KERR (1987: 90-95) and CARVALHO (2001), who also wrote important papers on the topic. However, the results obtained in my experiments presented here, and in observations of Bombus terrestris (Linnaeus, 1758) in the Netherlands (DUCHATEAU et al. 1994: 267-269), conclude that, under different circumstances, certain factors may lead to different results and conclusions in relation to diploid males, inbreeding and small Hymenopteran populations.

According to the WHITING (1934) principle, a new laying queen in an inbred and isolated Meliponini colony would have a 50\% chance of producing a 50\% usuless homozygous diploid male brood. The colony would die out for this reason. This could happen every time the isolated colony changes queens. The $50 \%$ chance of dying out would occur in an inbred colony every three years (average), since this seems to be the normal life span of a Meliponini laying queen.

In my inbreeding and population building experiments, when the old laying queen dies, one of her daughters has to mate with a brother or with a genetically equivalent bee, belonging to the same pool of chromosomic sexual alleles and of other genes existing in the small population.

Each experiment to build up a population from a foundation stock of one or a few isolated colonies means that all the individuals from this population belong to the same small genetic pool, restricted by inbreeding and genetic drift. 
Before establishing any general conclusions, it is necessary to discuss each one of our experimental results, to see how they fit or don't fit the WHITING (1934) principle and the 40 and 44 minimum number of colonies theory of KERR \& VENCOVSKY (1982) and KERR (1985).

First, it is necessary to examine and compare the overall number of dead colonies, against the number of colonies alive in different age groups. This is important to establish how many laying queen replacements occurred, in order to have a better understanding of the general genetic situation.

To estabilish how often a laying queen is replaced, it is necessary to consider how long her life span is. In the past, I saw two cases in which M. quadrifasciata marked queens lasted about two years. KERR (in WILSON 1971: 429) stated that a M. quadrifasciata queen lived three years and one month. In the absence of further data, we can say that a three years average life span seems to be a reasonable number for Meliponina queens.

We should always take into account that, in most of the inbreeding and population building experiments reported here, there were many colonies within the age bracket of over six months and under three years, in September 2001. In this case the existence of only one queen in a colony was considered. Another consideration is that there were also other colonies between three and six years old. In this age bracket, each colony had an initial laying queen that probably died when the colony was on average three years old. When this happened the dead queen was replaced by a new one. Therefore, colonies in the three to six year-old bracket had, on average, two succeeding laying queens, that is, the initial queen and the one that later replaced it. Going further, when dealing with Meliponina colonies in an age bracket of over six years, we must consider that there was an initial laying queen and probably two other succeeding queens: one when the colony began and one for each successive period of three years.

However, when computing the total number of succeeding queens that were in activity in an inbreeding and population building experiment, the population foundation queens were not considered because they were not born during the experiment.

A M. quadrifasciata quadrifasciata population was estabished in Itanhaém, on the Atlantic coast, in São Paulo State. The bees came from the Itajaí Valley (Santa Catarina). Started in 1991 from a single foundation colony in Itanhaém (São Paulo), this population had 22 colonies alive in November 1998, when this experiment ended. One colony remained in Itanhaém. Later, another one was brought to Cambory, near the seashore in São Sebastião (São Paulo).

As shown in greater detail in the section on results, the following situation prevailed in the Itanhaém stage of the M. quadrifasciata quadrifasciata inbreeding and population building experiment, in December 1998. Colonies alive under six months old: none. Colonies alive between six months and three years old: 7. On average, they probably did not have queen replacements; therefore, only the initial queens were counted. Colonies alive between three and six years old: 13. Each colony probably had, on average, two laying queens: the initial one and another one that replaced it when the colony was about three years old. Colony alive at six years 
of age or over: one colony. It had an initial laying queen, which was probably replaced when the colony was three years old, and another replacement when the colony was six years old, on average. Therefore, it had three succeeding laying queens. One colony remained in Itanhaém and another one was sent to Cambory (São Paulo). Both meliponaries are near the Atlantic shore. The total number of laying queens that were probably active during this experiment: 35 . The foundation queen and the colony were not counted. Colonies that died during the experiment: 5. There would have been seven normal live and active queens to compare with each colony that died with its queen. If the natural replacements of queens are not considered, there were 22 live colonies and five dead colonies. These ratios cannot be explained by the WHITING (1934) principle or by the KERR \& VENCOVSKI (1982) and KERR (1985) theory.

As mentioned above, two colonies were given away. After they were brought to Limeira in the highlands of São Paulo State, the remaining stock of 20 colonies produced through divisions 18 other colonies; three of these did not rear brood and were not counted under the discussion section of this paper. However, between the time they arrived in Limeira through September 2001, 19 colonies died, including colonies that came from Itanhaém. This represented a population crash. It occurred mostly during the year 2000, when 13 colonies died. In 1999, four colonies died, and in 2001, one colony died up to September. Only 16 colonies survived. It is difficult to tell what caused this high mortality. Generally speaking, they had too much sugar syrup in their food pots. They had been overfed. There were also clear signs of severe stress. Some colonies (numbers 40,41, 42) even shut their entrances, with a mixture of clay and propolis, that became very hard after it dried, chiefly the clay. It was so hard. that it seemed it would not be possible for them to reopen the entrance of the hive alone, so I decided to help. Only colony number 40 survived.

The population crash probably occurred because the subspecies $M$. quadrifasciata, found in Fazenda Tabajara, Limeira, did not adapt well to certain environmental conditions. In its Itanhaém stage, the experiment revealed that, under favorable ecological conditions and in the absence of severe stress, the WHITING (1934) principle does not work. However, in this case, the same bee population of $M$. quadrifasciata quadrifasciata, probably suffered severe ecologic stress when it was moved $190 \mathrm{~km}$ to another region, different from its native habitat. This experiment showed that approximately half of the colonies died in their Limeira stage, a fact that would fit the WhITING (1934) principle. It could also be a direct result of ecological stress. However, the different results in the Itanhaém and in the Limeira stages fit well the hypothesis presented here.

In Campinas, a $M$. quadrifasciata anthidioides inbreeding and population building experiment began effectively with a single foundation colony in 1991. Up to September 2001, no colonies in this experiment died before building brood combs. One colony was removed from the meliponary and sent to another locality at the age bracket of six months to three years old. 12 colonies were alive between three and six years old. When each one of these colonies started up, it had an initial laying queen that was replaced by another one (on average) when the colony was about three years old. Therefore, these 12 colonies had a total of 12 
initial queens and 12 of their replacements. Another 12 colonies were over six years old. These colonies had an initial queen and also had, on average, two changes of laying queens, meaning a total of 36 laying queens. In all, not considering the foundation queen, there were a total of 60 new laying queens. During the entire experiment, only two colonies died. This means that there were 30 laying queens belonging to live colonies in this experiment in relation to each colony that died with its queen. If the natural replacement of queens in a colony is not taken into account, it is possible to consider simply that there were 24 live colonies and only two colony deaths in this experiment up to September 2001. These numbers cannot be explained by the WHITING (1934) principle or by the KeRR \& VENCOVSKI (1982) and KeRR (1985) theory.

In Campinas, a Tetragona clavipes inbreeding and population building experiment began with a single foundation colony from Cosmópolis (São Paulo). Up to September 2001, three colonies died when they were under six months old. Another colony died before building brood combs, and therefore was not counted in this section. Five other colonies died when they were between six months and three years old. In September 2001, 14 colonies were alive at ages between six months and three years. Each one of these colonies probably had an average of only one new queen. However, the five colonies that were alive at ages between three years and six years had two succeding laying queens in each colony. One of these queens was the colony's initial one, and the second laying queen was its replacement, a fact that probably occurred arround the colony's third year. There were also three colonies over six years old. In this case, each colony had an initial laying queen that was probably replaced in the colony's third year. Another replacement would occur when the colony was about six years old, because the life span of a laying queen is approximately three years. This represents nine succeeding laying queens in each one of these colonies. Another relevant consideration is the important case of a remarkable colony of Tetragona clavipes that is the oldest Meliponini colony I still have alive. It is 42 years old (2001). This means that it probably had 13 changes of laying queens. It was the foundation colony of this stock. Therefore, only 12 changes in this colony will be counted here. Some $150 \mathrm{~m}$ from the meliponary, a swarm from the foundation colony, probably established itself, found in March 1986. It was still alive and strong in September 2001. It probably had five successive laying queens. If we consider all this data, in this inbreeding and population building experiment, there were eight dead colonies with their dead queens, as compared to 47 sucessive laying queens that belonged to 22 colonies alive in September 2001. This means a ratio of 1 dead colony, and its dead queen, to 5.8 successive laying queens that belonged to 22 of the colonies that are still alive. If queen replacements are not considered, there would be eight dead colonies to 22 colonies still alive at over six months old in September 2001. Both these ratios contradict the WHITING (1934) principle and the KeRR \& VENCOVSKI (1982) and KerR (1985) theory.

A Scaptotrigona postica inbreeding and population building experiment also began in Campinas in 1991 with five colonies mostly from the region of Cosmópolis. However, one of the five foundation colonies was a colony in which I successfully 
introduced a queen that Luiz Juliani sent me from Londrina. The following data is related to experiments and observations explained in greater detail in the section on the results. The following data describes the situation in Campinas in September 2001. Foundation stock: five colonies including an introduced laying queen, as mentioned above. Colonies under six months of age: none. Colony still alive between six months and three years old: 1 . Because of its age, this colony probably had only one initial laying queen. Colonies between three years and six years old: 7. Each one of these colonies first had an initial laying queen, but when it died at three years old (average), a young laying queen took its place. Colonies over six years old: 9 . Besides the initial laying queen, there were also two queen replacements (when the colony was three years old, and when it was six years old, on average). Colonies over nine years old: 3 . Each one of these colonies had an initial laying queen and also two successful changes of queens. The five population foundation colonies of this population where not counted in the total number. Considering all the data in this inbreeding and population building experiment, there was one dead colony and its dead queen, compared to 50 initial and successive laying queen replacements in the 21 colonies still alive. If replacement laying queens are not considered, the comparative ratio would be one dead colony to 21 live colonies. Obviously this data show that the WHITING (1943) principle and the related KERR \& VENCOVSKI (1982) and KERR (1985) theory do not fit what happened to this experiment's inbred colonies of Meliponini bees.

A Melipona rufiventris rufiventris inbreeding and population building experiment began at the Fazenda Aretuzina, in São Simão in 1993 with a foundation colony from Luziania. More details may be seen in the section on the results. The data stated below represent the situation in September 2001. Colony under six months old, that died before producing brood combs: 1 (number 22, not counted in the discussion of this paper). Colonies still alive between six months old and three years old: 13 . Because of their age, these colonies probably had only the initial laying queen. Colonies still alive between three and six years old: eight colonies. Each colony had an initial laying queen that was three years old (average) when she was replaced by another laying queen. Colonies still alive over six years old: 2 . These colonies had an initial laying queen and probably also had a first replacement of the queen at about three years old, and a second replacement at about six years old. Colonies that died after they started building brood combs: 9 . Population foundation colony (number 1): not computed in this discussion section. Considering all the data in this inbreeding and population experiment, there were nine dead colonies with their nine dead queens, and 23 live colonies at over six months old. The 23 live colonies had 35 successive laying queens, therefore a ratio of one dead colony and its dead queen to 3.8 successive queens belonging to each colony still alive. If replacement queens and colonies under six months old are not considered, there were nine dead colonies compared to 23 colonies still alive in September 2001, a ratio of one dead colony to 2.4 live colonies. These records also show that the WHITING (1934) principle and the KERR \& VENCOVSKI (1982) and KERR (1985) theory do not give a valid interpretation of what happened in this inbreeding and small population experiment. 
The inbreeding and population building experiment with Melipona scutellaris, began in 1996 at the Fazenda Aretuzina, São Simão with two colonies sent by Renato Barbosa from their native habitat in Pernambuco State, approximately 1,200 $\mathrm{km}$ away. The situation of this population in September 2001 is presented here. Both population foundation colonies were later joined by two others from the same stock, as will be commented below. Colonies still alive between six months and three years old: 20. Each colony probably had only one initial laying queen, because of its age. Colonies still alive between three and six years old: 5 . Each one of these colonies probably had an initial laying queen that was replaced by another laying queen after three years because of its age. Two other colonies were also within this same age bracket, but each should be counted as having only one replacement laying queen, because they are population foundation colonies. Their initial laying queens were born before the experiment began and therefore were not counted. Colonies that died over six months old and after they started building brood combs: 2 . Another two colonies that died, as mentioned earlier, were possibly foundation colonies that arrived late and in poor condition. I wrongly thought that they could recover. They remained alive only for 10 months, in spite of the several brood reinforcements they received. Their queens were possibly laying a great deal of sterile eggs. Because of their poor condition, perhaps they probably did not contribute to the genetic pool and should not be truly considered as part of the foundation stock. However, to avoid needless discussion, they were qualified as foundation colonies. In short, if one counted the colony deaths as well as the initial colony queens and their replacements (except for the population foundation colonies in relation to their initial queens), there would be four colony deaths with their dead queens, compared to 30 successive laying queens belonging to 25 colonies still alive at over six months old as existing in September 2001. If the replacement queens are not considered, the comparative numbers would be four dead colonies to 25 live colonies at over six months old. This means a ratio of one dead colony to 5.2 live colonies. This data contradicts the WHITING (1943) principle and the KERR \& VENCOVSKI (1982) and KERR (1985) theory.

Jatiara Farm, in Luziânia, received a stock of three Melipona scutellaris colonies sent from Recife. I began an inbreeding and population building population experiment with these bees a long way $(1,000 \mathrm{~km})$ from the species' native habitat. Nine colonies were between six months and three years old. Certainly all of them had only one initial queen each. Three other colonies, at ages between three and six years old, could each have two successive queens, because the average lifetime of these queens is about three years. However, the first queen of the only surviving colony of the three population foundation colonies was not counted, because she was born before the experiment started. Therefore, a total of 12 colonies were alive and counted in September 2001, with 14 successive laying queens. Up to that time, colonies that died with their queens: 3 . Four other colonies under six months old died, but were not counted here because they did not rear brood. If only the colonies and not the queens were counted, there would be a ratio of one dead colony to four live colonies. These numbers also contradict the WHITING (1943) principle and the KERR \& VENCOVSKI (1982) and KERR theory. 
There is an inbreeding and population building experiment with Melipona quinquefasciata colonies at the Jatiara Farm, Luziânia. This species occupies subterranean cavities formerly escavated by Atta sp. ants. This is a remarkable bee, the tamest of all the Melipona Illiger, 1806, I have worked with. In the meliponary, the hives of this species must always be kept under the soil or in special shelters with dry sand covering the hives (but not their entrances). In September 2001, as the data in the results section shows, 12 colonies were alive within the age bracket of six months to three years old. Each one of these colonies would have an average of one initial laying queen. Two other colonies alive within the age bracket of three to six years, would have two successive queens each. However, one of these colonies is the foundation colony of this population. Therefore, only one of the two successive queens of this colony was counted. In all, there were 14 colonies alive at over six months old, with 15 successive laying queens. Two colonies died at over six months old and one at under six months old, but already building brood combs. Another colony younger than six months also died but was not counted in this discussion section, because it did not build brood combs. Therefore, there were only three colonies counted as dead, a ratio of one dead colony and its queen to five successive and successful laying queens. If the successive laying queens were not counted, there would be a ratio of one dead colony to 4.6 live colonies. Another colony died before it was six months old, but it never built brood combs. Therefore it was not counted in this discussion section. The data presented here cannot be explained by the WHITING (1934) principle or by the KERR \& VENCOVSKI (1982) and KERR (1985) theory.

Something very unexpected happened in Campinas. From a single population foundation colony of Scaptotrigona xanthotricha, a Trigonina that came from Serra da Bocaina somewhat $200 \mathrm{~km}$ NE of the spot, I was able to build up a population of 21 colonies from 1995 to January 2000. In July 2000, a frost killed a weak colony, and only 20 colonies were left alive. However, it seems that now many of the colonies belong to $S$. postica. The $S$. xanthotricha can be easily distinguished from the $S$. postica kept and breeding in the same meliponary, due to the orange coloring of several parts of their body. Scaptotrigona postica is a dull black bee with yellowish hairs on the back of it abdomen. Scaptotrigona xanthotricha also has similar hairs, but S. postica is mostly a dark bee. Scaptotrigona xanthotricha is mostly an orange colored bee. No dark bees were seen in this population, up to September 1999. To my surprise, I noticed that, in that month, half of the 14 then existing colonies were made up of dark colored bees. Later, in November 2000, only six colonies from a population of 20 live colonies, were chieffy orange colored. This requires further study. The dark bees are identical or almost identical to $S$. postica. It could be that the dark bee is a hybrid, but this is very unlikely. More probably, a young $S$. postica queen invaded a $S$. xanthotricha colony and became the accepted new laying queen, true to what WHEELER (1922-1923) called Temporary Social Parasitism. This name means that the colony, after some time, only has bees that are daughter and sons of the accepted invader queen. It also happens amongst some ants.

A sideline result of the $S$. postica invading case is the fact that, in an average of 10 cases, possibly the $S$. xanthotricha queens lasted 21.3 months, before dying and being replaced by a $S$. postica queens. However, the queens were not marked 
and in some colonies there could have been queen replacements. After November 2000, I saw no new cases of Temporary Social Parasitism in the São Quirino meliponary.

Perhaps a special environmental condition enabled these successful invasions, because after some time they stopped occurring. For the purpose of this study, only the colonies with orange colored bees should be considered, because only these are real $S$. xanthotricha bees. In all, from November 1995 to early 2000, 10 colonies of true $S$. xanthotricha bees were still alive. By December 2000, only six colonies had survived. They are strong. In September 2001, two colonies still remain in the São Quirino meliponary (Campinas). Four colonies were removed from the $S$. postica colonies and taken to the Usina Ester meliponary (Cosmopolis) in April 2001. These six colonies were still S. xanthotricha, by September 2001.

The cases presented above clearly show that, in 9 different experiments, the WHITING (1934) principle and the related KeRR \& VENCOVSKI (1982) and KERR (1985) theory did not explain the results, including the first stage (in Itanhaém) but not the last stage with a population crash (in Limeira) the M. quadrifasciata quadrifasciata experiments reported here.

In spite of the existing data that disproves the WHITING (1934) principle, some other data could favour it, including the population crash mentioned above. In my research, it was not possible to establish a new and isolated Meliponini population in several instances because both the foundation and the resulting 1 or 2 new colonies died off after one or more divisions. This happened in 1993 in Itanhaém, with Melipona scutellaris from Lençois, Bahia State and with M. rufiventris rufiventris from Luziania in 1994. A similar situation occurred in the meliponary established in Luziania with a foundation colony of M. subnitida from NE Brazil and its "daughter" colony. Both died (1998). Two colonies ("mother" and "daughter") of $M$. quadrifasciata quadrifasciata also died in the Luziania meliponary. The foundation colony came from the Itajaí Valley in 1991. In addition, in Luziania, a foundation colony of $M$. quadrifasciata anthidioides from São Simão produced five "daughter" colonies through divisions. Five of these six colonies died and only one was alive in November 2000. It was still well in September 2001. Also, in Luziânia, a stock of $M$. scutellaris from Lençóis (Bahia State) had two founding colonies and a "daughter" colony in 1993. They all died in 1995. However, another stock from the same species, but from Pernambuco State, later fared very successfully in Luziania, in the same meliponary. In Campinas and in Cosmópolis the breeding of $M$. rufiventris soon failed. In these eight experiments with four species of Melipona, it was not possible to start new populations from one or from a few foundation colonies of non-native Meliponini. This failure seems attributable to ecological or other forms of stress, possibly causing the production of diploid males directly or indirectly.

An unusual experiment result is worthy of special consideration. In Cosmópolis, a stingless bee population was begun in 1991 with a single foundation colony belonging to the local stock of $M$. quadrifasciata anthidioides. This population grew to 11 colonies and then declined to three colonies by 1997 (eight dead and three alive). Moreover, during the population crash that occurred in 1995, with the death 
of six colonies, there were possible signs of the presence of diploid males. There were fights inside one of the hives and a queen was killed in the same colony (number 10). This particular colony died only six years later. In June 1998, nine colonies had died and only three remained alive since the beginning of the experiment. The total number of colonies that had died since the beginning of the experiment was 15 (over a 10-year period) by September 2001. This also includes a second population crash, with the death of four colonies, between July and September 2001. No males were noticed before the colonies died. These four colonies had plenty of pots with honey or with sugar syrup. There were five normal colonies over six months old (one over three years old) alive in September 2001. All in all, the M. quadrifasciata anthidioides population in the Cosmópolis meliponary had an effective ratio of 15 dead to five live colonies, or one dead colony to 0.3 live colonies. The up-down-up trends in the number of live and dead colonies may be explained by my hypothesis of the existence of a sex determining substance, the production of which could be partly influenced by environmental factors. A stingless bee population of the same subspecies ( $M$. quadrifasciata anthidioides), belonging to a similar population inbreeding experiment held at the Fazenda São Quirino in Campinas, some $43 \mathrm{~km}$ SE of Cosmópolis, had a very different result, as shown in this paper. It had no population crashes and only two dead colonies in 10 years. In yet another case, the experiment held with $M$. quadrifasciata quadrifasciata (another subspecies) in Limeira, reported earlier, also had a population crash. Limeira is only about $20 \mathrm{~km}$ NW of Cosmópolis. Limeira, Cosmópolis and Campinas are all in the same region of São Paulo State and apparently have the same ecosystems.

It is very difficult to determine exactly why nine other inbreeding experiments failed and why there was a rapid increase in the number of colonies followed by a first crash (1995) and later by a second crash (2001) in the Cosmópolis inbreeding population experiment. However, the fact that this small population from Cosmópolis started with a single colony and survived 11 years, in spite of two population crashes, cannot be well explained by the WHITING (1943) principle or by the KERR \& VENCOVSKY (1982) and KERR (1985) theory only. As I mentioned before, the Meliponini are certainly very sensitive to stress brought on by environmental factors. In previous publications (NOGUEIRA-NETO 1997: 73-75, 1999), I referred to the importance of stress in relation to the behavior and the survival of stingless bees. I defined stress as "the condition that results from any continuous pressing factor that may modify or supress the natural physiological processes and the normal behavior of a single individual or a group of individuals (such as a colony), causing harm and even death in the most severe cases" (NOGUEIRA-NETO 1999, modified here). From 1948 to 1970, some 30 colonies of Meliponini bees from several distant regions were introduced in my meliponaries in Cosmópolis, São Simão, Campinas, and chiefly in São Paulo city. Some colonies came from Barra do Corda, Maranhão State: Melipona flavolineata Friese, 1900 or M. rufiventris and $M$. compressipes fasciculata. A colony of $M$. flavolineata also from Barra do Corda, lived well in São Simão. It was not clear if the specimens from Barra do Corda were $M$. flavolineata or $M$. rufiventris. I received $M$. seminigra merrillae Cockerell, 1919 and M. compressipes manauensis Schwarz, 1932, from Manaus, 
Amazonas State, whereas M. scutellaris came from the States of Sergipe and Alagoas. A colony of this species, from one of these States, lived for about three years in São Simão, but not in Campinas, Cosmópolis or São Paulo city. This was before 1970. I received M. rufiventris mondori Smith, 1863 and M. bicolor schencki Gribodo, 1893, from the São Francisco do Sul Island and the Itajaí Valley in Santa Catarina State. Nearly all of these colonies died less than one year after they arrived. The males and virgin queens in a colony of $M$. rufiventris and also in a colony of M. mandacaia did not mate during the winter. For data on all these species, see NOGUEIRA-NETO (1970: 66, 69, 73, 81, 90, 91, 94, 252-253; 1997: 234-238). Because of the more developed technology available today, like simpler and more efficient ways to protect colonies against the cold weather, it became possible to rear $M$. rufiventris rufiventris more successfully. In relation to this species, new and improved technologies (NOGUEIRA-NETO 1997) have apparently prevented or reduced stress in São Simão more effectively than in Luziânia. A single foundation colony that came from Luziânia started a successful population in São Simão. Melipona scutellaris was also reared very successfuly in São Simão, as well as in Recife, from where the foundation colonies came. This occurred in spite of the great climatic differences between both sites, meaning that diverse species of the Meliponini may react in distinct ways.

In 1948, I sent 10 colonies of Meliponini to the United States Department of Agriculture, and 20 others in 1950. They were forwarded to Baton Rouge (Lousiania), Tucson (Arizona), Davis and Palo Alto (California), Logan (Utah) and Beltsville (Maryland). A Nannotrigona testaceicornis Lepeletier, 1836, lived two years in Baton Rouge (with Dr. W. Whitcomb) and a Plebeia sp. lived eight years in Palo Alto (with Prof. G. Schafer). The other colonies died in less than one year (NogueIRA-Neto 1997: 38-39). João Pedro Cappas e Sousa is trying to maintain several species of Meliponini in Southern Portugal (Alentejo), but this has not been an easy task. All these cases are mentioned to show that climatic stress may limit the survival of stingless bees. Most species of Meliponini do not have large habitats, certainly because they may be constrained by considerable ecological stress in areas outside their boundaries.

Therefore, I arrived at the conclusion that what I call "ecological stress" (NOGUEIRA-NETO 1997: 73), and other stress factors, are of paramount importance in the lives of the Meliponini (NOGUEIRA-NETO 1999). However, there are also localities far outside native habitats where the ecological and physiological conditions in the colonies may be improved by good breeding technologies (NOGUEIRANETO 1997). This seems to be very important for some species of non native Meliponini. Apparently, as was reported here, this is taking place on the Fazenda Aretuzina, in São Simão, with a population of Melipona scutellaris, a stingless bee from Northeastern Brazil, and on a lesser scale in Luziania with the same species and stock. There may also be a kind of ecological compensation in places where very favorable local ecological factors would compensate for other ecological factors that are not so well suited for these bees.

When several of my results began to show disparaty with those of WHITING (1943) and with the hypotheses of KERR \& VENCOVSKI (1982), and KERR (1985) 
it became clear that something not expected by these authors was occurring. A new explanation was needed. There are observations by other authors that also cannot be explained by the traditional Whiting principle.

Different findings and sets of facts gave me the chance to formulate a new preliminary working hypothesis to explain what could be happenning at the molecular level in relation to sex determination in the Meliponini (NOGUEIRA-NETO 1900a, b, 1996a, b, 1997: 66-77, 1999). This hypothesis is now ready and mature enough to be presented on a broader level. Of course, it may also be applied to other Hymenoptera.

Everybody agrees that the expression of a biological character basically depends on the genes of an individual, and also on external factors. However, some people tend to give more importance to the genetic code, and pay less attention to the influence of the environment. As we all know, genes and environment should always be seen as closely connected or integrated factors. It is well-known that regulatory genes are put into action by outside or inside cell conditions. When we speak of the function of alleles in the chromosomic sexual locus of the Meliponini, we must realize that the expression of these and other genes is conditioned, in the real world, by the animal ecology and ethology. This also includes the animal's physiology.

It is important to note that KERR et al. (1966) showed that the combination of genes (a certain double heterozygosis), necessary for the production of queens in Melipona, also depends on environmental conditions (nutritive) for genetic expression of the queen. This dependency had not been foreseen before.

Long ago, SCHMIEDER \& WHITING (1947) reported important research on the wasp Melittobia chalibii, and three other species, all of them endogamous Chalcidoid parasites. Two stocks of an undescribed species were used, one in 87 inbred generations, and another in 109 inbred generations (data also in SCHMIEDER 1933, 1938, who did the techmical work). These authors stated that in spite of repeated inbreeding there was no production of diploid males, and no eggs that failed. This finding was very important, because it clearly showed that, under some circumstances, the Whiting principle does not work. Therefore, a new hypothesis was needed, and I may add that it had been needed practically ever since the Whiting principle was stated, as Whiting himself demonstrated, in his joint paper with Schmieder (SCHMIEDER \& WHITING 1947).

In the Netherlands, DUCHATEAU et al. (1994: 267-269) reported that, within a two year period, a total of 86 colonies of Bombus terrestris were established by colony founder queens captured in the Gimborn Arboretum, but no diploid males were produced. No existing formulas (LAIDLAW et al. 1956; CORNUET 1980; KERR \& VENCOVSKI 1982) could use this result to estimate correctly the number of sex alleles. The numbers would be too high. Also in the Netherlands, the situation of $B$. terrestris contrasts sharply with the situation of this species introduced in the island of Tasmania, Australia. Researchers BUTTERMORE et al. (1998), studying the offspring of 100 field queens captured in Tasmania, found that "about $50 \%$ of the adult-producing colonies produced sex rates consistent with male diploidy". The authors cited above said that this situation suggests "that the entire Tasmanian 
population may have descended from one inseminated queen". In my opinion, the large spread of a population with 50\% diploid males among the diploid individuals was possible, in the case of Bombus terrestris in Tasmania, partly because, among bumble bees, only one bee (a fecundated young queen) establishes a new nest. There is no swarming in $B$. terrestris, a behavior that is complex and requires many workers and more food resources in the Meliponins and in Apis mellifera. Moreover, since B. terrestris is the only Bombus present in Tasmania, there was a lack of competition from related species. This certainly helped the spread of this bee in Tasmania, in spite of the presence of diploid males in many colonies.

It seems clear that the production of diploid males in B. terrestris depends greatly on environmental conditions, since the presence or absence of male diploids was found to differ substantially between the Netherlands, where they are native, and Tasmania, where they have recently been introduced, somehow.

In Apis mellifera, diploid male individuals are a minor drawback to their colony. Viable diploid male larvae "were eaten by the workers shortly after hatching" (WOYKE 1963 apud WOYKE 1980). A colony may survive relatively well in such a situation. However, in the Meliponini, the diploid male larvae are not killed. They eat the same amount of food as the normal workers and haploid males. Therefore, diploid male brood use a substantial amount of the larval food resources of a colony, but don't work when they become adults. For all these reasons, a Meliponini colony with many diploid males always perishes or becomes very weak.

In order to explain the results of my experiments, Professor Warwick E. Kerr told me personally that it would be difficult to discover all the existing colonies of Meliponini bees living in a given area. I agree that this really may be very difficult or even impossible, particularly when colonies are inside cities. However, if there are only a few unnoticed colonies, this would not have a significant influence on the final result, if the 40 or 44 colonies hypothesis is considered. What really counts in such hypothesis is that successful Meliponini reproductive populations should have at least 40 or 44 colonies in order to survive.

Should anyone wish to repeat the inbreeding and population building experiments described here, it would probably not be difficult to meet the population isolation requirements. Inside large habitats of native stingless bees, it is quite possible to find many areas free of colonies of a chosen species, required to avoid outside crossings. Another consideration is that the experiments reported here were made in different localities and with different species.

The experiments reported here in detail, with Melipona scutellaris in São Simão and in Luziania were made respectively $1,200 \mathrm{~km}$ and $1,000 \mathrm{~km}$ from the habitat of this bee, in Northeastern Brazil. This species bred well in these localities far from its natural range, but its breeding failed in other distant places. The presence or absence of various degrees of stress could explain the differences determining colony survival.

The success of the breeding experiments of $M$. rufiventris rufiventris in São Simão, the breeding of $M$. quadrifasciata quadrifasciata in Itanhaém, and the rearing of $M$. quadrifasciata anthidioides, Tetragona clavipes and Scaptotrigona postica in Campinas, and of M. quinquefasciata in Luziânia, occurred in local areas 
where these species were not present. However, these are areas that in the past were probably inside the species' habitat before agriculture and other man-performed activities changed natural biotas and landscapes.

The successful cases of the inbreeding and the building up of small populations of Meliponini reported here, followed a general pattern comprising of: a) geographic isolation in areas near or far from the presently known habitat of the species; b) relatively low colony mortality c) generally no large numbers of males; d) nearly always no killing of bees inside the hives; e) many strong or many medium populated colonies; f) few weak colonies.

Theoretically, Meliponini males may travel several kilometers, feeding here and there on flowers. In so doing, they probably arrive within the boundary of another population, not too far away. However, it is important to note that the Meliponini do not produce scents that could attract individual bees a long distance away. The known odor trails of stingless bees are composed of many scent marks that are only a few meters apart (LINDAUER \& KERR 1960: 37-67). CARVALHO \& KERR (2000) also presented an experiment in which all the 40 males let free from 100 to $400 \mathrm{~m}$ away from their meliponary returned to it. However, when the distance was $1000 \mathrm{~m}$, only two out of ten males returned. This seems to indicate that odor is not a major factor that may attract males to a meliponary, from a long distance.

Another important question, in relation to the production of diploid males, is to know if a Meliponin queen mates once or several times (multiple mating). KERR \& KRAUSE (1950) stated that Melipona quadrifasciata queens mate only once. However, IMPERATRIZ-FONSECA et al. (1997) and also IMPERATRIZ FONSECA et al. (1998), observed and reported a multiple mating of Tetragonisca angustula Latreille 1811, that occurred on the main campus of the Universidade de São Paulo. PETERS et al. (1998) examined the genotypes of bees belonging to 13 species of Meliponins, and 10 genera. "In six out of the 12 single-queen species, all worker genotypes were consistent with a single, once-mated queen ..." "The small number of anomalies in the remaining species could arise" from several causes including multiple mating.

Concurring with Prof. Velthuis and Prof. Imperatriz-Fonseca (whom I talked to personally), I have the impression that in many species of stingless bees, the queen mates only once, but there are other species in which the queen has or may have multiple matings. I also agree with these collegues in thinking that these species, which may have great congregations of males near their nests, are the ones with a greater probability of having multiple matings among their young queens.

CARVALHO (2001), in an experiment with M. scutellaris, found "that $65.5 \%$ of matings occurred with one male, and $34.5 \%$ with two males." The calculation was based on the number of diploid males in eight years of observation. The smaller percentage is related to two matings.

Single matings fit the main hypothesis presented here very well. Multiple matings should be seen as a way by which some species of Meliponini may keep more sexual alleles in their populations. On the species level, these matings seem to be related to the presence of large numbers of laying workers inside the hive. In my opinion, there was probably a co-evolution of queen multiple matings in many species with the existence of laying workers (not mated) in the colony, and also the 
presence of large agglomerations of males near some stingless bee nests. In these situations, a colony has a large number of drones that may act as a reservoir to maintain the different sexual alleles that were present in their grandmothers spermatheca. In turn, these different sexual alleles enable multiple matings to bring several of these alleles to the spermatheca of new queens. It may be a cycle in a sequence: many sexual alleles-many males-multiple matings-many sexual alleles and so on. It should be noted, also, that the presence of many laying workers in queen-right colonies increases the number of reproductive bees and therefore lessens the effects of genetic drift. This drift is responsible for the loss of gene alleles (Sewall-Wright principle). In large populations of some Meliponini species, the cycle mentioned here will maintain itself.

In a recent paper, STRASSMANN (2001) wrote that "the overwhelming majority of species of social ants, bees and wasps mate only once. Even those species where some females mate multiply typically have effective mate numbers close to one." I also agree with her saying that "what is clear is that single mating is predominant in this large, evolutionarily and ecologically successful group" (= Hymenoptera). As I see it, the loss of part of the sexual alleles by genetic drift in small populations would soon turn the colonies of species with multiple matings genetically similar to the foundation colonies of single mating species. As shown in most of the experiments reported here, under normal ecological circumstances, the loss of many sexual alleles is not disruptive in a Meliponini population. However, it may be disruptive in other circumstances, when there is severe stress.

In the context of the main working hypothesis presented here, the existence and maintenance of several sexual alleles in a population may be important to some stingless bee species, to gain greater heterozygosis in the sexual locus; a similar situation may occur in other loci. At times, this may be necessary to enable populations to overcome stress factors by favoring hybrid vigor, that would promote better survival rates in unfavorable situations and better conditions for the species to expand their habitats. This could perhaps explain the difficult question of the adaptive value of the WHITING (1934) principle. It also fits well with the main hypothesis presented here, on the production of a sex determining substance (see chief conclusions).

A few more things should be reported about laying workers. SAKAGAMI \& ZUCCHI (1963: 505) were the first to write about laying workers in queen-right colonies of the Meliponini. In relation to Scaptotrigona postica, BEIG (1968: 32) and $\operatorname{BEGO}(1982,1990)$ noted that a large proportion of the males present in a colony may be produced by laying workers. L.R. Bego (1998 personal information) also found that in seven colonies of that species, $44 \%$ of the workers had fully developed ovaries. They produced two kinds of eggs: reproductive and trophic. SiLVA (1977: 62-63) compared the numbers of male sons of a $M$. quadrifasciata anthidioides queen and the number of male sons of workers. In one colony, almost all the males were sons of the queen during 16 months. In another colony, with a $M$. quadrifasciata quadrifasciata queen, almost all males were sons of laying workers during 16 months. Likewise there were times in which no males or only a few were produced, and other times when large numbers of males were produced. The data about laying 
workers in Tetragonisca angustula seems to be incomplete. According to observations by Dr. Dick Kodean, workers had reproductive eggs inside their abdomen, but no laying activity was observed (personal information from Bego in 1998). As I see it, one of the chief adaptive benefit of having many laying workers is that these workers produce only normal haploid males in a colony. Also, the sons of a large number of laying workers seem to be useful for keeping different alleles in their population. Furthermore, because of the activity of laying workers in normal colonies, the queen would be enable to lay more female eggs, since she would not have to lay many male eggs. However, stress may break down this state of social homeostatic equilibrium.

In Friseomelitta varia there are no laying workers (information given by Yoko Terada in 1974). CAPPAS E SouSA (1992: 58-69) referred to special workers ("queen-workers") of $M$. quadrifasciata that produced workers. This was observed in Alentejo, Portugal, in colonies sent there from Paraná State, Brazil.

Universities in Brazil, as well as in other parts of the world are doing DNA research, using Meliponini bees. When completed, the research is expected to show important features of Meliponini genetics.

It would also be very interesting and important to discover the precise locus of the sexual alleles of the Meliponini and to recognize these alleles. BEYE et al. (1996) wrote about their important research to find the sex locus of Apis mellifera in the chromosome eight of these bees.

I have not yet made any cytological exams of the chromosome counts of colony broods suspected of having stingless bee diploid males. In my experiments, this would interfere with the results. It would be necessary to remove and kill the imature bees of whole brood combs, in order to examine and count their chromosomes. This would create stress in the colonies and would weaken them, procedures which I have always tried very hard to avoid. Weak colonies would obviously be more sensitive to stress factors, or could result from a stressful situation or else increase it, creating a vicious circle. Actually, some of the different results obtained around the world in studying live animals could be attributed to different laboratory stresses. This is very hard to avoid. In the case of the experiments to detect the presence of diploid males, excessive handling of colonies is not uncommon and often leads to stresses that are difficult to assess.

The manner in which the colonies die or survive may give a good indication of the existence or absence of diploid males. If they are present, even if the Meliponini colony has plenty of food, it will probably not survive more than a few months. I reinforced colonies only by giving them brood combs of strong colonies or by enabling them to receive adult workers from strong colonies by moving a weak colony to the site of a robust and heavily populated colony which is moved to another place. These measures were taken to overcome temporary problems, but offered no on-going help. Colony failures occurred even when temporary help was provided, possibly indicating the presence of a laying queen that produced diploid males. It is important to note that these reinforcements were always made using brood or adult bees from strong "sister" colonies of the same population, that is, belonging to the same genetic pool. Only once were new genes introduced in populations, 
reported here in the section on results. This happened in São Paulo City, when Melipona quadrifasciata anthidioides genes appeared in a $M$. quadrifasciata quadrifasciata population, unexpectedly.

In my inbreeding and population building research, the concept of viewing each population of colonies as a genetic pool is a fundamental consideration.

There is also a pioner research made by KERR \& NIELSEN (1967) in Rio Claro and Ribeirão Preto. They studied imbreeding by dividing seven colonies of $M$. scutellaris, three of $M$. seminigra merrilae, two of $M$. marginata, one of $M$. rufiventris, one of $S$. xanthotricha, one of Meliponula bocandei (from Angola). "The highest percentage mortality of any queen was only $11.4 \%$ and all the emerging bees were female". The authors stated that "we can conclude that at least some species of stingless bees do not possess $\mathrm{x}$ alleles which cause $\mathrm{x} / \mathrm{x}$ to become males". Afterwords this conclusion was not repeated.

\section{CONCLUSIONS}

Below, I present two main sets of findings and also a few suggestions for further research. This paper shows that it is possible to build up Meliponini populations starting with only one or a few foundation colonies. Therefore, it is not necessary to investigate the actual presence of diploid males to arrive at the conclusion that the Whiting (1934) principle is often not valid. Other evidence shows that the Whiting principle and the 40 or 44 minimum colony hypothesis seem to be correct only under certain circumstances, when there is a high level of stress. Evidence on the failure or inadequacy of the WHITING (1934) principle in a number of instances, and of the Kerr and Vencovsky hypothesis, is presented in the section on the discussion.

Some facts, discussed earlier in this paper, that were studied by SCHMIEDER \& Whiting (1947, on Melittobia Westwood, 1847), and by Duchateau et al. (1994, on Bombus terrestris), may also be explained by the working hypothesis stated here, but not by the WHITING (1934) principle. It is important to note that the WHITING (1934) principle itself, with its limitations, can be explained on the molecular level, according to the working hypothesis presented here, as follows.

The interrelation between stress levels and nutritive biologic products present in the eggs of the Meliponini and in the genetic constitution of the embryos would certainly influence the amount of a sex determining substance produced at a very early developmental stage in bee embryos. Obviously there is some kind of sex determining substance. It may be a simple enzyme, but is more likely to be a complex substance necessary for sex determination. If the pair of allele genes present in the sexual locus of a certain pair of chromosomes is made up of two alleles of the same type (a homozygous situation), in this case alone, the high nutritive condition of the egg would allow a sufficient production of the sex determining substance. In other words, given very good ecological, nutritive and physiological conditions, plus low levels of stress, even the homozygous diploid offspring of the laying queen would be female. 
If both alleles present in the sexual locus are of different types (a heterozygous situation) they would always lead to the production of a larger amount of the sex determining substance, even if the particular nutritive status of the egg is relatively low. It is a well-known fact that heterozygosis is often responsible for a greater production of biological products (hybrid vigor). I mentioned a high or a low nutritive value only in a general sense. No data exist on the number or on the composition of all biological products present in Meliponini eggs. However, it is a well-known fact that the amount of larval food ("royal jelly") is important in determining the queen's caste in the Trigonina sub tribe of stingless bees. The very special case of queen determination in Melipona (here considered as belonging to the sub tribe Meliponina) also involves genetic and nutritive factors (KERR et al. 1966). It is always important to remember that genes may fully express their potential only if they are in the cells of living beings that are properly fed and not subject to serious stress. Normal physiological processes are checked or altered by stress, a fact that has received little attention from bee researchers in general.

The combination of a low nutritive condition, chiefly resulting from stress, with the presence of a homozygous pair of sex alleles, would not produce a sufficient amount of a sex determining substance. As a result, half of the diploid inbred offspring (all the bee embryos that are homozygous in the sexual locus) of a laying queen become useless diploid males.

Except in Melittobia spp. and similar parasitic wasps that have no diploid males, the WHITING (1934) principle states that a homozygous situation in the sexual locus of a Hymenoptera individual would produce a diploid male. However, the results presented here suggest that this only occurs in the Meliponini when, in addition to a homozygous situation in the sexual loci, there is also a stressful situation, due to unfavorable conditions. Stress may cause the failure or partial failure of physiological processes. All this would result in the production of eggs of low nutritive value, probably containing a small amount of trophic proteins. Bees certainly receive most of the aminoacids they need from the proteins which exist in the pollen they gather, and which they later break down through digestion. Some Trigona Jurine, 1807, use animal tissues as a source of protein (ROUBIK 1982; CAMARGO personal communication, 1991). The aminoacids are essencial for make up proteins, such as the enzyme or enzymes producing the sex-determining subsance (probably hormone-like) referred to here. Considering the expanding body of knowledge available today on DNA, RNA, ribosomes, enzymes, operon cluster genes, regulatory genes etc., it seems difficult to accept that Hymenoptera sex determination is established directly by the mere presence and combination of certain allelic genes in the sexual locus, without considering other factors and even other genes.

Another matter that should be considered here is the fact that all normal. Hymenoptera males have a haploid genetic situation since they have a single set of chromosomes. This means that lethal or semi-lethal genes can be more easily eliminated from the Hymenopteran populations through the course of evolution, because, in haploid individuals, these dangerous genes cannot hide as recessive 
genes under the cover of favorable dominant genes, as may happen in a heterozygotic diploid condition. This also means that inbreeding in bees, ants and wasps, in a general sense, is usually safer than in many other groups and kinds of animals, provided there is no severe stress.

So that we may better consider the complexity of the matters discussed, a few basic steps should also be borne in mind.

Although difficult to demonstrate at the molecular level, the basic sex-determining substance certainly would be produced by chemical reactions catalyzed by enzymes. All the enzymes are the result of the action of genes (DNA) that send the information necessary to produce the needed proteins in the cell ribosomes, through a messenger RNA. Existing among the proteins produced in the early bee embryo (all bees have a sex) are the enzymes needed to produce the sex-determining substance. Aminoacids are the basic "raw materials" of all proteins. The special substance that would activate male or female genes present in the embryo is produced through these and other procedures. A small amount of this substance would give rise to male genes. Haploid individuals, because they have only one set of chromosomes, would always produce a small amount of the sex determining substance. Therefore, all haploid bees become males. If there is only a low level or a small amount of the sex-determining substance, this would also activate the male genes that exist in all homozygous diploid individuals of a colony. These embryos will become diploid males. However, the heterozygous embryos of a colony will become females, because the production of a sex-determining substance in these embryos is always at a high level. In addition, a high quantity of the sex-determining substance, promoted by good nutrition and by the absence or near absence of stress will activate only the female genes in all diploid embryos of a colony, whether they are homozygous or heterozygous. I am referring to homozygosis or heterozygosis in the sexual locus. These are what I consider the main premises of my basic hypothesis, on the molecular level.

In the concept postulated by BRITTEN (apud TAMARIN 1996: 413-416), the amount of protein production may depend on the existing number of copies of a certain gene. The making of copies is possible through what could be called, "gene amplification," or by other means such as the repetitive presence of microsatellite genes. I believe that all this productivity depends additionally and in all certainly, on an adequate supply of nutrients, including aminoacids, which in turn depends on the lack of any serious stress. Hybrid vigor could mean that, in a heterozygous situation, more copies of a gene would be present and would be triggered and put into action. However, this is only a possibility, and should be considered an eventual hypothesis to be tested at the molecular level.

KERR et al. (1996) stated that the activation of females genes in bees depends on the amount of juvenile hormone produced by each bee during its immature stage. These authors think that a sexual homozygous diploid bee is always a male because it would produce only a small quantity of juvenile hormone. I believe that we still don't know the mature and composition of the sex determining substance. On diploid males I already expressed here my opinion. 
SNELL (1935) and also CROZIER (1971, 1977: 264-265, 281) in earlier papers, considered that Hymenoptera sex determination could be attributed to the genes present in several loci of the chromosomes. In my opinion, production of the sex-determining substance, that is a basic part of the main working hypothesis presented here, could be influenced by factors other than the homozygous or heterozygous situation in the already well-known pair of chromosomic sex locus mentioned by WHITING (1943) and other authors. This production could also be affected in some way by one or by several nutritive biological products that are present in the eggs. These nutritive biological products may result, at least in part, from the activity of enzymes determined by several genes present in other chromosomic loci. I think that the action and productive ability of the genes of these other loci would also depend greatly on the available aminoacids and on the levels of stress present in the colony as a whole, and in its bees as individuals. More must be known about its mature and also how the sex-determining substance is produced and how it acts, but I believe that the general picture has been drawn here.

It may take years of research to secure the molecular details of the hypothesis presented here. The chief aim of this paper is to present the results of several inbreeding and population building experiments with Meliponini bees. This data has made it possible to discuss and to arrive at some broad conclusions. They constitute the mainstream of my hypothesis on sex determination in Meliponini bees and probably in other Hymenoptera as well.

ACKNOWLEDGEMENTS. I would like to thank Sandra Camerata and Clemilde Soares Pociano da Silva, secretaries; Wilson Carlos de Lima e Sousa, former driver, helper and carpenter (he also brought a colony of $M$. subnitida from Rio Grande do Norte); Juvenal Nascimento Flor, helper and driver; Mario Ribeiro, carpenter; José Vicente Caixeta, Aparecido Leite, Darcy Hickmann, Nelson Gomieiro, Paulo Rubilson, Genario Nascimento da Silva, and Servilio Homura, helpers; Lauro Schluter, who obtained colonies of Melipona quadrifasciata in Santa Catarina; Renato Barbosa, who obtained colonies of $M$. scutellaris in Pernambuco; Ana Maria Lopes Menezes, who sent me colonies of this species from Lençois, in Bahia; Luiz Costa, who brought Scaptotrigona xanthotricha from Serra da Bocaina (SP); Henrique Carazola, José Correia, Antonio Francisco, Luiz Costa, field finders of bee colonies. Thanks are also due to Professor Dr. Vera L. Imperatriz-Fonseca, to Dr. Marilda Cortopassi-Laurino, Prof. Dr. Dov Por, to the Bee Laboratory of the Departamento de Ecologia, Instituto de Biociências, USP, Prof. Dr. Vinalto Graf, Departamento de Zoologia, UFPR, to Mr. Richard Jones (IBRA); to N. Cristina Martorana for reviewing nearly all the text and my English, and to Usina Açucareira Ester (logistics). Last, but not the least, my thanks to Sociedade Brasileira de Zoologia (President Dr. Olaf H.H. Mielke and Editor Dr. Mirna M. Casagrande) that accepted this paper for publication, to the anonymous reviewers and to all the other people and institutions that helped me on this project. No funding grants were requested or received for this 10 year work.

\section{REFERENCES}

BEGo, L.R. 1982. On social regulation in Scaptotrigona postica Latreille, with special reference to male production cycles. Bol. Zool. Univ. São Paulo 7: 181-196.

Revta bras. Zool. 19 (4): 1181 - 1214, 2002 
1990. On social regulation in Nannotrigona (Scaptotrigona) postica Latreille, with special reference to productivity of colonies. Revta bras. Ent. 34: 721-738.

Beye, M.; R.F.A. Moritz; R.H. Crozier \& Y.C. Crozier. 1996. Mapping the sex locus of the honeybee (Apis mellifera). Naturwissenschaften 83: 424-426

Buttermore, R.E.; N. Pomeroy; W. Hobson; T. Semmens \& R. Hart, 1998. Assessment of the genetic base of Tasmanian bumble bees (Bombus terrestris) for development as pollination agents. Jour. Apic. Research 37 (1): 23-25.

CAmargo, C.A. 1974. Produção de machos diploides de Melipona quadrifasciata. Ci. Cult. 26 (7): 267.

. 1979. Sex determination in bees. XI. Production of diploid males and sex determination in Melipona quadrifasciata. Jour. Apic. Research 18 (2): 77-78.

CAPPAS E SouzA, J.P. 1992. Os meliponineos em Portugal e na Europa. Actas do V Congresso Ibérico de Entomologia. Bol. Soc. Portuguesa de Entomologia 1 (Supl. 3): 53-68.

CARvalho, G.A. 2001. The number of sex alleles (CSD) in a bee population and its practical importance (Hymenoptera, Apidae) Jour. Hymenop. Research 10 (1): 10-15.

Carvalho, G.A. \& W.E. Kerr. 2000. Informações sobre a vida reprodutiva da uruçú (Melipona scutellaris Latreille) e da tiuba (Melipona compressipes fasciculata Smith). Eymba Acusy 1 (4): 2 .

CORnuET, J.M. 1980. Rapid estimation of the number of sex alleles in panmitic honeybee populations. Jour. Apic. Research 19 (1): 3-5.

Crozier, R.H. 1971. Heterozygozity and sex determination in haplo-diploidy. Amer. Naturalist 105 (945): 399-412.

- 1977. Evolutionary genetics of the Hymenoptera. Ann. Review Entomol. 22: 263-288.

CUNHA, A.B. DA \& W.E. KERR. 1957. A genetical theory to explain sex determination by arrhenotokous parthenogenesis. Forma Function 1 (4): 33-36.

Duchateau, M.J.; H.Hoshiba \& H.H. Velthuis. 1994. Diploid males males in the bumble Bombus terrestris. Entomol. Exp. Appl. 71:263-269.

IMPERATRIZ-FonsECA, V.L.; H.H. VelthUis \& E. Matos. 1997. Multiple mating in native stingless bees. Ann. XXXV International Apicultural Congress, Apimondia: 73-74.

Imperatriz-Fonseca, V.L.; E.T. Matos; F. Nogueira-Ferreira \& H.H. Velthuis. 1998. A case of multiple mating in stingless bees (Meliponinae). Insects Soc. 45: 231-233.

KERR, W.E. 1974. Sex determination in bees. III. Caste determination and genetic control in Melipona. Insectes Sociaux 21 (4): 357-368.

- 1985. Número máximo e mínimo de colonias de Meliponineos que devem ser colocados em um local. Bol. Capel., Belo Horizonte, 40: 7-8

1987. Sex determination in bees. XXI. Number of heteroalleles in a natural population of Melipona compressipes fasciculata. Insectes Sociaux 34 (4): 227-279.

Kerr, W.E. \& W. Krause. 1950. Contribuição para o conhecimento da Bionomia dos Meliponini. Fecundação da rainha em Melipona quadrifasciata Lep. Dusenia, Curitiba, 1: 275-282.

KERR, W.E. \& R.A. NieLSEN. 1967. Sex determination in bees (Spinae). Jour. Apic. Research 6 (1): $1-9$.

KERR, W.E. \& R. VENCOVSKI. 1982. Melhoramento genético em abelhas. Efeito do número de colonias sobre o melhoramento. Rev. Bras. Genét. 5 (2): 279-285.

Kerr, W.E.; A.C. Stort \& M.J. Montenegro. 1966. Importância de alguns fatores ambientais na determinação das castas do gênero Melipona. An. Acad. Brasil. Ciên. 38 (1): 149-168.

Kerr, W.E.; G.A. Carvalho \& V.A. Nascimento. 1996. Abelha uruçu. Belo Horizonte, Editora Acangaú, 143p.

LAIDLAW, H.H.; F.P. GOMES \& W.E. KeRR. 1956. Estimation of the number of lethal alleles in a panmitic population of Apis mellifera. Genetics 41 (2): 179-188.

Lindauer, M. \& W.E Kerr. 1960. Communication between the workers of stingless bees. Bee World 41: 29-41, 65-71.

MacKensen, O. 1951. Viability and Sex determination in the honey bee. Genetics 36: 500-509. 
MiChEnER, C.D. 2000. The bees of the world. Baltimore, Johns Hopkins Univ. Press, 913p.

MoURE, J.S. 1951. Notas sobre Meliponinae. Dusenia, Curitiba, 2 (1): 25-70.

Nogueira-Neto, P. 1970. A criação de abelhas indígenas sem ferrão. São Paulo, Ed. Tecnapis, $2^{\text {a }}$ ed., $365 \mathrm{p}$.

1990a. The determination of sex and sexual characters in stingless bees. Publicações Tecnápis Ecologia Etologia, São Paulo, 1: 1-6.

1990b. Novas idéias sobre a determinação de sexo e castas nas abelhas indígenas sem ferrão.

Rev. Brasil. Apicult. 7 (39):32

1996a (2000). Inbreeding experiments in colonies of the stingless bee Melipona quadrifasciata (Apidae, Meliponinae). Proceedings Sixth International Conference on Apiculture in Tropical Climates (1996) IBRA, Intl. Bee Research Association, p. 162-166.

- 1996b. The survival of small populations of Scaptotrigona postica. An. 2 Encontro sobre abelhas, Ribeirão Preto, 2: 50-53.

- 1997. Vida e criação de abelhas indígenas sem ferrão. São Paulo, Edições Nogueirapis, ISBN-85-86525-01-4, 446p.

1999. Stressful situations and their consequences on sex determination and on the behaviour of stingless bees. Rev. Etologia 1 (1): 65-68.

Peters, J.M; D.C. Queller; V.L. Imperatriz-FonseCA; D.W. Roubick \& J.E. STRAsSMAnN. 1998. Mate number, kin selection and social conflits in stingless bees and honeybess. Proc. Royal Soc. London 266: $379-384$

ROTHENBUHLER, W.C. 1957. Diploid male tissue as new evidence on sex determination in honey bees. Jour. Heredity 48: 160-168

RouBIK, D.W. 1982. Obligate necrophagy in a social bee. Science 217: 1059-1060.

SAKAGAMI, S.F. \& R. ZUCCHI. 1963. Oviposition process in a stingless bee Trigona (Scaptotrigona) postica Latreille. Studia Entomol. 6 (1-4): 497-510.

SCHMieder, R.G. 1933. The polymorphic forms of Melittobia chalybii Ashmed and the determining factors imolved in their production. Bio. Bull. 65: 338-354.

- 1938 The sex ratio in Melittobia chalybii Ashmed gametogenesis and cleavage in females and in haploid males. (Hymenoptera, Chalcidoidea, Eulophidae) Bio. Bull. 74: 256-266.

SCHMieder, R.G. \& P.W. Whiting. 1947. Reproductive economy in the Chalcidoid wasp Melittobia. Genetics 32: 29-37.

SiLVA, D.L.N. 1977. Estudos bionômicoa em colônias mistas de Meliponinae. Bol. Zool. 2 (4): 7-106.

SNELL, G.D. 1935. The determination of sex in Habrobracon. Genetics 21: 446-453.

StRassmann, J.E. 2001. The rarity of multiple mating by females in the social Hymenoptera. Insectes Sociaux 48: 01-13.

Tamarin, R.H. 1996. Princípios de Genética. Barcelona, Boston Univ., Editorial Reverte, 607p.

WHEELER, W.M. 1922-1923. Social life among insects. Constable \& Co Ltd. 37, on stingless bees mostly p. 121-133.

Whiting, P.W. 1943. Multiple alleles in complementary sex determination in Habrobracon. Genetics 28: 365-382.

WiLSON, E.D.O. 1971. The insect societies. Belkanp, Harvard Univ. Press, 548p.

WOYKE, J. 1963. Drone larvae from fertilized eggs of the honeybee. Jour. Apic. Research 2 (1): 19-24 1980. Effect of Sex allele homo-heterozygosity on honey bee colony populations and their honey production. Jour. Apic. Research 19 (1): 51-63.

Yokoyama, S. \& M. Nei. 1982. Population dynamics of sex-determinining alleles in honeybees and self-incompatibility alleles in plants. Genetics 91: 609-626.

Received in 11.III.2002; accepted in 07.X.2002. 